\title{
PERCEPTIONS OF SCIENCE TEACHERS TOWARDS SCIENCE TEACHING IN SECONDARY SCHOOLS IN LAGOS STATE, NIGERIA
}

\author{
FLORENCE OMOSHOLAPE ABIDOYE \\ Department of Science Education, University of Ilorin, Nigeria.
}

\begin{abstract}
The objective of this study was to determine the perception of science teachers towards science teaching in senior secondary schools in Lagos State, Nigeria. Specifically, the study determined the perception of science teachers towards science teaching on the basis of their gender and years of teaching experience. It was a survey research in which simple random sampling technique was used to select 275 science teachers from secondary schools in Lagos state, Nigeria. Two hundred and eight five Science teachers were sampled from senior secondary schools, of the 285 questionnaires distributed, 275 were retrieved. The data collected were analyzed using frequency count, percentages and t-test. These were used to answer the research questions and also test the hypotheses. The findings of the study showed that: (i) science teachers generally had positive perception towards science teaching $\left(t_{\text {cal. }}=20.43\right.$ at $\left.p<0.05\right)$; (ii) there was no significant difference in the perception of science teachers towards science teaching based on their gender $\left(t_{\text {cal. }}=0.39\right.$ at $\left.p>0.05\right)$; and (iii) there was no significant difference in the perception of science teachers towards science teaching based on their years of teaching experience $\left(t_{\text {cal. }}=1.40\right.$ at $\left.p>0.05\right)$. The implications are discussed
\end{abstract}

Keywords: Perception of science teachers, science teaching, senior secondary schools,

DOI: $\quad$ https://doi.org/10.35386/ser.v18i1.25

\section{Introduction}

Science is a systematic process of obtaining testable knowledge about nature and natural occurrence, utilizing careful observation and experimentation (Okeke, 2007). It has also been defined as a body of knowledge, a way of investigating natural phenomenon or a method and a way of making judgment in the pursuit of an understanding of nature (Abimbola \& Omosewo, 2006). Science is a great enterprise which nations depend on, in order to advance technologically; therefore, it receives much emphasis in education due to its significance and relevance to life and society (Nwagbo, 2008).

According to Oludipe and Lasisi (2006), advances in science and technology call for the provision and utilization of resources which tend to enhance the effective teaching and learning of science. Consequently, science teachers play an integral role in the teaching and learning of science as they stimulate students thinking, and make learning enjoyable, interesting, exciting and concrete (Obomanu, 2011).

Teachers have various roles to play in the processes of teaching and learning, most especially in teaching of science subjects. For instance, they need to be competent in their subject areas of specialization and also be able to apply different methods of teaching and strategies and understand the learning process of students (Ololube, 2009). 
In addition, the teachers' knowledge of the subject matter and the method of teaching are known to be highly important in bringing about good performance among the students (Shulman, 1994). Therefore, teachers who are specialists in a particular subject should normally be more effective than non-specialist teachers. This is because teachers are faced with problems when they venture into areas where they do not have adequate content and pedagogical knowledge to establish an environment that is conducive to learning.

Teachers are regarded as the basic tools in education and curriculum implementations. The quality of any nations' education is determined by the qualities of the teachers and their attitude to the profession (Afolabi, 2007). Richard and Gema (2009) found out that teacher's quality is a key element of students' academic success, but few specific teacher characteristics influence classroom outcomes. Olatoye and Ogunkola (2004) observed teacher qualification and experience as predictors of attitude towards science teaching and they found out that the qualifications of science teachers have influence on students' performance while the teaching experience does not have any such influence. Teaching experience is a vital tool point in the science teaching and learning situations.

Ezenweani (2002) defined teaching as the ability to guide one to gain knowledge in a classroom setting, the teacher does the work of guiding the learner through social interactions (student-teacher, student-student) to gain experience that are worthwhile for social living in a larger society. Abimbola (2009) defined teaching as a process of facilitating students' learning through a proper management by the teaching of the interrelationship among the students' interests, the content for learning and the materials he/she tends to use in teaching and learning of the content. This study investigated the science teachers' perception to science teaching in Lagos State, Nigeria on the basis of their gender and years of teaching experience.

\section{Purpose of the Study}

The main purpose of the study was to determine the perception of science teachers towards teaching in Senior Secondary Schools in Lagos State, Nigeria.

Specifically, this study investigated:

1. the perception of science teachers towards science teaching in Senior Secondary Schools in Lagos State, Nigeria.

2. the perception of science teachers towards science teaching based on their gender.

3. the perception of science teachers towards science teaching based on their years of teaching experience.

\section{Research Questions}

Answers were provided to the following research questions:

1. What is the perception of science teachers towards science teaching in Senior Secondary Schools in Lagos State, Nigeria? 
2. What is the perception of science teachers to science teaching based on gender?

3. What is the perception of science teachers to science teaching based on their years of teaching experience?

\section{Research Hypotheses}

The following hypotheses were formulated and tested in this study:

1. There is no significant difference in the perception of science teachers towards science teaching based on their gender.

2. There is no significant difference in the perception of science teachers towards science teaching based on their years of teaching experience.

\section{Scope of the Study}

The geographical coverage of this study was science teachers in all Secondary Schools in Lagos State, Nigeria. Teachers of Biology, Chemistry, Physics, Agricultural science and Mathematics were involved in the study. This study focused on finding the perception of science teachers towards science teaching.

\section{Population, Sample and Sampling Technique}

The population of this study comprised all the science teachers in secondary schools in Lagos State, Nigeria. The target population for the study comprises 275 science teachers in 75 secondary schools in 15 local Government Areas in Lagos State, Nigeria. Stratified sample procedure was used to select 27 secondary schools in the 15 Local Government Areas that were involved in the study.

\section{Methodology}

This research was a descriptive survey in which data were collected from a sample of individuals from a specific population. The sampled population was asked questions according to standardized procedures, with the aim of obtaining a composite report of the population, with regards to the research questions and the objectives of the study. Data obtained were used to describe the perception of science teachers to science teaching.

This study was carried out in Senior Secondary schools in Lagos State, Nigeria. This included 275 science teachers (Biology, Chemistry, Physics, Mathematics and Agricultural teachers) in 27 selected Secondary Schools across 15 Local Government Areas in Lagos State, Nigeria. Variables that were tested in the study were: gender and years of teaching experience of Science Teachers. The instrument for this study was questionnaire which consisted of two sections (sections A and B); Section A of the questionnaire requests for personal information of the Science teachers such as; school name, teachers' gender and years of teaching experience. Section B of the questionnaire contains 40 statements representing opposing viewpoints of the influence. The responses to the questionnaire items are on a five Likert scale such as Strongly Agree (SA), Agree (A), Undecided (UD), Disagree (D) and Strongly Disagree (SD). 
The validity of the instrument was done by researcher's supervisor, one professor, two Science Education lecturers in the Department of Science Education, and one lecturer in area of Test and Measurement Faculty of Education University of Ilorin for both face and content validation. Their observations and comments were effected to further sharpen the focus of the research instrument. In addition, the research instrument was administered to 40 Science teachers at three weeks interval in some secondary schools in Lagos State (who did not take part in the study). The reliability of the instrument was determined using test retest method. The instrument was administered to science teachers from four schools. Data obtained from the four schools were correlated using Pearson-Product Moment Correlation Coefficient Formula which gave a reliability coefficient of 0.891 . The coefficient value obtained $(r=0.891)$ indicates that there is a high correlation between the two scores.

The perception of science teaching scale was adapted and prepared with the 40 valid items. The maximum possible score was 100 and the minimum was zero. A low score indicates the presence of negative perception to teaching and any value above the average value of 80 indicates positive perception of teachers towards science teaching. The researcher personally visited the selected schools to administer the instrument after obtaining the permission of the appropriate authorities. The administration of the questionnaires was done with the help of the Heads of Science Departments in each of the selected school. Science teachers were encouraged to be objective in their responses. The researcher waited and collected the filled questionnaires immediately and others that could not be collected were done after a week.

\section{Results}

\section{Research Question 1:}

What is the perception of science teachers towards science teaching?

\section{Research Hypothesis 1:}

There is no significant difference in the perception of science teachers towards science teaching in senior secondary schools in Lagos State, Nigeria.

Table 1: Summary of Mean Score and t- test for testing perception of Science Teachers' towards Science Teaching in Lagos State, Nigeria

\begin{tabular}{lllllllll}
\hline & $\begin{array}{l}\text { Numbe } \\
\mathrm{r} \text { of } \\
\text { respon } \\
\text { dents }\end{array}$ & & Score & $\begin{array}{l}\text { Maximu } \\
\text { Score }\end{array}$ & $\begin{array}{l}\text { Mean } \\
\text { Score }\end{array}$ & $\begin{array}{l}\text { Std. } \\
\text { Deviation }\end{array}$ & df & p-value \\
\hline Total & 275 & 67 & 100 & 82.85 & 6.67 & 20.43 & 274 & 0.00 \\
\hline
\end{tabular}

Table 1 shows the numbers of responses of science teachers towards science teaching in senior secondary schools in Lagos State, Nigeria. The individual perception towards science teaching scores for all the science teachers were found out and they were valued from the highest to the lowest scorer. Scores above 80 were positive perception and those below 80 scores were negative. The total number of respondents 
was 275 science teachers, the minimum score was 67 and the maximum score was 100.

The mean score was 82.85 . This was found to be significantly higher than the cut off mean score of 80 . The perception of science teachers towards science teaching was significantly positive since $\mathrm{p}$-value $(0.00)<0.05(\mathrm{t}=20.43$; df 274 and $\mathrm{p}$-value 0.00$)$. Thus, the null hypothesis one $\left(\mathrm{Ho}_{1}\right)$ which states that there is no significant difference in the perception of science teachers towards science teaching in senior secondary schools in Lagos State was rejected. This shows that science teachers in the Lagos State generally had positive perception towards science teaching.

\section{Research Question 2:}

What is the perception of science teachers to science teaching based on their gender?

\section{Research Hypothesis 2:}

There is no significant difference in the perception of science teachers to science teaching based on gender.

Table 2: $\quad$ Mean Scores and t-test for testing attitude of Science Teachers in Lagos State, Nigeria based on Gender

\begin{tabular}{|c|c|c|c|c|c|}
\hline Gender & $\begin{array}{l}\text { No of } \\
\text { Respondents }\end{array}$ & $\begin{array}{l}\text { Mean } \\
\text { Score }\end{array}$ & $\begin{array}{l}\text { Standard } \\
\text { Deviation }\end{array}$ & $\begin{array}{l}\text { Std. Error t } \\
\text { Mean }\end{array}$ & df $p$-value \\
\hline Male & 166 & 82.73 & 6.98 & $0.54 \quad 0.39$ & $273 \quad 0.27$ \\
\hline Female & 109 & 83.05 & 6.19 & 0.59 & \\
\hline
\end{tabular}

Table 2 shows the mean scores for male 82.73 and for female 83.05 and that no significant difference exists between the perception of male and female science teachers since the p-value $(0.27)>0.05$. The perception of female science teachers is however slightly more positive.

The perception of science teachers is positive towards science teaching. The null hypothesis $\left(\mathrm{Ho}_{2}\right)$, which states that there is no significant difference in the perception of science teachers towards teaching by gender is upheld

\section{Research Question 3:}

What is the perception of science teachers towards science teaching based on their years of teaching experience?

\section{Research Hypothesis3:}

There is no significant difference in the perception of science teachers towards science teaching based on their years of teaching experience. 
Perceptions of Science Teachers towards Science Teaching in Secondary Schools in Lagos State, Nigeria

\begin{tabular}{llllllll}
\hline Table 3: & \multicolumn{6}{l}{$\begin{array}{l}\text { Mean Scores and t-test for testing perception of Science Teachers' } \\
\text { in Lagos State, Nigeria based on experience }\end{array}$} \\
\hline Experience & $\begin{array}{l}\text { No of } \\
\text { Respon } \\
\text { dents }\end{array}$ & $\begin{array}{l}\text { Mean score } \\
\text { Standard }\end{array}$ & $\begin{array}{l}\text { Std. Error t } \\
\text { Deviation }\end{array}$ & df & p-value \\
\hline $\begin{array}{l}\text { Less } \\
\text { experience } \\
(0-5)\end{array}$ & 124 & 83.48 & 6.91 & 0.62 & 1.40 & 273 & 0.201 \\
$\begin{array}{l}\text { Experience } \\
\text { (above } \\
\text { 5years) }\end{array}$ & 151 & 82.34 & 6.45 & 0.53 & & & \\
\hline
\end{tabular}

Table 3 shows the mean scores and reveals that there are no significant differences in the perception of science teachers towards science teaching based on their experience in Lagos State, Nigeria since the p-value $(0.20)>0.05$. The mean scores range between 83.48 and 82.34 with those with less experience having slightly higher positive perception. The null hypothesis $\left(\mathrm{Ho}_{3}\right)$, which states that there is no significant difference in the perception of science teachers towards science teaching based on years of experience is upheld.

\section{Summary of Findings}

The research findings of this study as obtained from t-test based on the Research questions and hypotheses are summarized as follows:

1. Science teachers had positive perception towards science teaching in the senior secondary school in Lagos State, Nigeria.

2. The perception of science teachers towards science teaching is not based on gender.

3. The perception of science teachers towards science teaching does not depend on their years of teaching experience.

\section{Discussion}

It was found that the perception of science teachers towards science teaching in senior secondary schools in Lagos State, Nigeria was significant based on their responses which were above the average score of 80 , meaning that they had positive perception towards science teaching. It can also be as a result of helpful behaviour, resourcefulness, enthusiasms, good method of presentation, concern for students and teacher knowledge of the subject matter and the acceptance that they are role model. This is in agreement with the findings of Standslause, Maito and Ochiel (2013) which examined teachers' and students' attitudes towards mathematics and found that mathematics teachers had positive attitude towards mathematics teaching. Similarly, Merfat, Saed and Enass (2011) studied Jordanian early childhood teachers' perspectives towards science teaching and learning and the result indicated that the teachers had positive attitudes towards teaching.

It was established in this study that there was no significant difference in the perception of science teachers towards science teaching based on their gender. The male and female science teachers had positive perception towards science teaching. 
This may be hinged on the fact that intelligent is not gender based. The little difference may also be associated with some other feature that are peculiar to each gender such as the rate at which that operate tender to oppress man (pride and rivalry). This is in agreement with the findings of Udousoro (2012) who investigated the effect of gender and Mathematics ability on academic performance of students in Chemistry. The results of the test indicated that gender did not have any significant effect on the academic performance of students in Chemistry. Abimbola and Abidoye (2013) observed the views of Kwara State senior school Biology teachers on the status of ecology teaching and the result indicated that there is no significant difference in the views of male and female biology teachers. This is also in line with the finding of Owolabi and Adebayo (2012) that investigated the effect of teacher's qualification on the performance of senior secondary school physics students and deduced the implications on technology in Nigeria. The result indicated that gender differences of the teachers had no effect on their ability to impact knowledge.

It was observed from the findings of this study that there was no significant difference in the perception of science teachers towards science teaching based on their years of teaching experience. It may also be due to the fact that the experienced and lessexperienced science teachers have mastered the content and acquired classroom management skills to deal with different type of classroom problems. In addition, it may be as a result of their determination to show that they can deliver their subject matter well. This is in agreement with the finding of Abimbola and Abidoye (2013) that studied the views of Biology teachers on the status of ecology teaching and the result indicated that those views did not vary significantly with their teaching experience.

Merfat, Saed and Enass (2011) observed that Jordanian early childhood teachers' perspectives towards science teaching and learning and the result indicated that the no of years of experience of science teachers had no significant difference on their attitude towards teaching. However, this is in contrast to the finding of Gbore and Daramola (2013) that investigated the relative contributions of selected teachers' variables and students' attitude towards academic achievement in biology and found that significant relations existed in the experience of biology teachers and students' academic achievement in biology.

\section{Conclusion}

Based on the findings of the study, the study concluded that science teachers had positive perception to science teaching in Lagos State, Nigeria based on their responses which were above the average score. The perceptions of science teachers towards science teaching based on their gender and years of teaching experience were generally positive towards science teaching in the analysis conducted. That is, there was no significant difference in the perception of science teachers towards science teaching. 
Perceptions of Science Teachers towards Science Teaching in Secondary Schools in Lagos State, Nigeria

\section{Recommendations}

The implications of this to science teaching in secondary schools are:

1. Science teachers should have a good perception of science teaching in order to encourage students.

2. Both the male and female science Teachers should learn how to improve on the perception to science teaching.

3. The experienced and less experienced science teachers should be encouraged to acquire more experience in order to improve on their perception towards science teaching. 


\section{References}

Abimbola, I. O. (2009). A brief history of teaching. In Abimbola , I. O. \& Abolade, A. O. (Eds.) Fundamental Principles and Practice of Instruction. Departments of Science Education and Arts and Social Sciences Education, University of Ilorin, Ilorin Nigeria.

Abimbola, I. O. \& Abidoye, F. O. (2013) Effect of qualification and experience of biology teachers on the status of ecology teaching in Kwara State. Journal of Education and Practice, 4 (24), 1-8.

Abimbola, I. O. \& Abidoye, F. O. (2013). Views of Kwara State senior school Biology teachers on the status of ecology teaching. Journal of Curriculum and Instruction, 8 (1), 1-10.

Abimbola, I. O. \& Omosewo, E. O. (2006). History of science for degree students. Ilorin: Oyinwola Printing Works.

Afolabi, F. (2007). Teachers' attitude and gender factor as determinant of pupils' performance in primary science. African Journals Online: www.ajol. Info 3 (1), 326-332.

Ezenweani, U. L. (2002). Experimental Mathematics Teaching. Enugu: Fuladu Publishing Company.

Nwagbo, C. R. (2008). Practical approach to effective teaching of local and major biotic communities (Biomes) to Secondary School Students for Sustainable Development. Science Teachers' Association of Nigeria (STAN) Biology Panel series.

Gbore, L. O. \& Daramola, C. A. (2013). Relative contributions of selected teachers' variables and students' attitude towards academic achievement in biology among senior secondary schools students. Academic Education Share Research, 16 (10), 35-41

Obomanu, B. J. \& Akporehwe, J. (2011). Resources for teaching Secondary School Biology in Bayelsa State of Nigeria. Information \& Knowledge Management, 1 (2): 28-35. Retrieved November 162012 from http://www.iiste.org.

Okeke, E. A. C. (2007). Making Science Education Accessible to all. $23^{\text {rd }}$ Inaugural Lecture Series, University of Nigeria, Nsukka. 
Perceptions of Science Teachers towards Science Teaching in Secondary Schools in Lagos State, Nigeria

Olaoye, R. A. \& Ogunkola, B. J. (2004). Teacher gender, qualification and experience as predictors of attitude towards science teaching in Lagos state secondary schools. International Journal of Emotional Psychology and Sport Ethics, 6, $39-44$.

Oludipe, O. \& Lasisi, I. T. (2006). Resources as enhancer of effective teaching and learning of primary science. Proceedings of the $47^{\text {th }}$ annual conference of STAN.

Ololube, N. P. (2009). Understanding Teachers' Professional Competencies for Education Effectiveness. Owerri: Springfield Publishers Ltd.

Owolabi, O. T. \& Adebayo, J. O. (2012). Effect of teacher's qualification on the performance of senior secondary school physics students: Implication on technology in Nigeria. Canadian Center of Science Education. Retrieved June 162014 from www.ccsenet.org/elt. 5 (6): 72-77.

Shulman, L. S. (1994). Those who understand: knowledge growth in teaching. Educational Researcher, 15 (4), 4-14.

Standslause, E. O., Maito, T. L. \& Ochiel, J.K. (2013). Teachers and students attitude towards mathematics in secondary schools in Siaya County, Kenya. Asian Journal of management Sciences and Education. 2 (3), 116-123.

Merfat, F., Saed, A. and Enass, O. (2011). Jordanian early childhood teachers' perspectives towards science teaching and learning. International Journal Research in Early Childhood Education, 2 (1), 76-95. www.education.monash.edu.au/irecejournal/

Richard, B. \& Gema, Z. (2009). What teachers characteristics affect student achievement. Journal of urban economics, 6 (2), 103-115.

Udousoro, U. J. (2012). The effect of gender and Mathematics ability on academic performance of students in Chemistry. African research review, an international multidisciplinary Journal of Ethiopia, 5 (4), 201-213. 